\title{
Jacobi i jego polemika z idealizmem transcendentalnym
}

Igor Nowikow (Adam Mickiewicz University)

\section{Wprowadzenie}

Friedrich Heinrich Jacobi (1743-1819) jest jednym z bardziej znanych krytyków idealizmu transcendentalnego Kanta oraz jego kontynuacji we wczesnych pracach Fichtego. Spór z filozofią idealistyczną podjął on między innymi w pracach: Meine Vorstellungen (1781), Epistel über die Kantische Philosophie (1791), Jacobi an Fichte (1799) oraz Abhandlung Über das Unternehmen des Kritizismus, die Vernunft zu Verstande zu bringen (1802). W niniejszym szkicu chciałbym skupić się na myślach zawartych w pracy Jacobi an Fichte, w której polemika $\mathrm{z}$ idealizmem Kanta i Fichtego przybiera niezwykle zdecydowaną formę. ${ }^{1}$ Jacobi argumentuje przeciwko tezie, że tylko rozum jest w stanie rozpoznać prawdę oraz uzasadnić wolność i etykę. Ta „pretensja” rozumu prowadzi, jego zdaniem, do konkluzji, że to, co miało zostać dowiedzione, czyli prawda, wolność i etyka, musi zostać - wbrew intencjom przedstawicieli filozofii idealistycznej - zanegowane. Aby temu zapobiec, wyodrębnia on obok prawdy intelektualnej drugi rodzaj prawdy: prawdę intuicyjną. Jacobi podkreśla jej egzystencjalny aspekt, odwołując się przy tym do zachodniej tradycji moralno-religijnej. Nie chcąc popaść w irracjonalizm, dąży on jednocześnie do tego, aby zharmonizować oba rodzaje prawdy. Ze względu na fakt, że daje on pierwszeństwo prawdzie intuicyjnej przed intelektualną, jego filozofia, jako całość, ma charakter bardziej praktyczny niż teoretyczny.

Niniejszy szkic składa się z trzech części. W części 1 zaprezentowany zostanie fundament myśli Jacobiego: jego rozumienie prawdy. W części 2 omówione zostaną konsekwencje, jakie $\mathrm{z}$ części 1 wynikają dla etyki $\mathrm{i}$ wolności. W obu tych częściach poglądy filozofa zostaną przedstawione na tle jego sporu $\mathrm{z}$ idealizmem transcendentalnym. Tłumaczeniom fragmentów tekstu Jacobi an Fichte towarzyszyć będą komentarze, mające na celu lepsze ich zrozumienie i powiązanie w spójną całość. W części 3 sformułowane zostaną konkluzje, jakie nasuwają się po dokonanej analizie.

\footnotetext{
1 Opieram się na następującym wydaniu: Friedrich H. Jacobi, Jacobi an Fichte, Hamburg: Friedrich Perthes 1799. Odniesienia do tej pozycji oznaczone są umieszczoną w nawiasie literą J wraz z numerem strony.
} 


\section{Fundament: „prawda” w rozumieniu Jacobiego}

\subsection{Jacobi jako kontynuator idealizmu kantowsko-fichteańskiego}

Zdaniem Jacobiego Kant jest „poprzednikiem Fichtego” („Vorläufer von Fichte”, J, VI); w kontekście obu tych filozofów używa on określenia „filozofia transcendentalna” („Transscendentalphilosophie”, J, VIII, IX) lub „idealizm transcendentalny” („transscendentaler Idealismus”, J, 4). Pomimo krytyki, jakiej poddaje ich filozofię, Jacobi przejmuje od nich rozumienie pojęć „wiedza” i „nauka”. Podobnie jak oni, uważa, że „nauka” („Wißenschaft”) polega na „samostwarzaniu przedmiotu” („Selbsthervorbringen ihres Gegenstandes”, J, 10). Jacobi podkreśla, że wielką zasługą Kanta i Fichtego jest odkrycie, że prawda poznawalna rozumowo nie odnosi się do „samej rzeczy” („die Sache selbst”), lecz jedynie do „kształtu rzeczy” („die Gestalt der Sache”, J, 26). Stwierdza on: „Odtąd nikt już nie może dłużej - prosząc przy tym o wybaczenie - marzyć przy pomocy rozumu. Nikt już nie może żywić nadziei, że odnajdzie w końcu prawdziwą kabałę, i przy pomocy liter i cyfr stworzy jestestwa i żywe siły. - Zaprawdę, wielki i dobry to uczynek dla rodzaju ludzkiego [...]" (J, 27). ${ }^{2}$ Jacobi przejmuje podstawową tezę Kanta, głoszącą, iż świat „rzeczy samych w sobie” istnieje, ale jest niepoznawalny: „nasz filozoficzny intelekt nie wykracza poza swe własne wytwarzanie” („unser philosophischer Verstand reicht über sein eigenes Hervorbringen nicht hinaus", J, 61n). Również kwestia istnienia Boga jest dla Jacobiego - podobnie jak dla Kanta - sprawą wiary, a nie wiedzy: „O Bogu nie można wiedzieć, można w niego jedynie wierzyć. Bóg, o którym można by wiedzieć, nie byłby żadnym Bogiem." (J, IX). Jacobi opowiada się zatem w istotnych kwestiach za idealizmem kantowsko-fichteańskim, dystansując się w ten sposób wobec racjonalnej filozofii przedkantowskiej.

\subsection{Krytyka idealizmu kantowsko-fichteańskiego. Pojęcie prawdy w sensie "das Wahre"}

Doceniając historyczną rolę Kanta i Fichtego, Jacobi formułuje jednak zasadniczy zarzut wobec ich filozofii: niesłusznie zawężają oni pojęcie prawdy do sfery intelektualnej. Oprócz prawdy intelektualnej, którą Jacobi oznacza wyrażeniem „Wahrheit”, dostrzega on również i drugi rodzaj prawdy, oznaczając go wyrażeniem „das Wahre” (J, 11). Prawda w tym sensie to „sama rzecz” (J, 26), „to, co ukryte pod zjawiskami”, „ich znaczenie”, „byt” (J, 28), a uchwycić ją może tylko uczucie. Chcąc podkreślić związek pomiędzy obydwoma rodzajami prawdy, a jednocześnie zaakcentować prymat tej ostatniej, Jacobi charakteryzuje prawdę w sensie „das Wahre” jako „podstawę całej prawdy” („der Grund aller Wahrheit”, J, 11).

2 Używając słowa „marzyć” („schwärmen”), Jacobi wyraźnie nawiązuje do Kanta. Por. Kant, Prolegomena do wszelkiej przyszłej metafizyki, która będzie mogła wystapić jako nauka, tłum. A. Banaszkiewicz, Kraków 2005, s. 72 (§ 35). 
Nawiązując do opinii Fichtego o Kancie, Jacobi zarzuca temu ostatniemu - nie bez racji - pewną niekonsekwencję. Kant chce mianowicie uzasadnić dualizm, rzecz sama w sobie - zjawisko, czysto rozumowo. Niekonsekwencja polega jednak na tym, że, będąc idealistą, „przemyca” on do swojej filozofii moment realistyczny: „rzecz samą w sobie”. Jacobi wskazuje na fakt, że dopiero Fichte pokonał tę niekonsekwencję, znosząc Kantowski dualizm (J, VIII). Kant miał wprawdzie słuszność, wskazując na obszar niewiedzy, ale jego błąd polegał na tym, że szukał uzasadnień rozumowych dla tego obszaru, a zatem starał się go jakoś wkomponować w swój system naukowy. Tymczasem dla Jacobiego prawda w sensie „das Wahre” leży w ogóle „poza nauką” (J, 11). „Miejscem prawdy“ nie jest nauka, lecz - jak to określa Jacobi - „świadomość niewiedzy“ („das Bewußtseyn des Nichtwissens”), którą filozof charakteryzuje jako „coś najwyższego w człowieku.” (J, VIII).

Znosząc Kantowski dualizm, Fichte uczynił całą rzeczywistość przedmiotem wiedzy. Wiedza ta nie odnosi się do świata takiego, jakim jest on niezależnie od człowieka, lecz jest jego wytworem. „Duch ludzki” staje się „stwórcą świata i stwórcą samego siebie” („Welt-Schöpfer, und - sein eigener Schöpfer", J, 16). Jacobi zwraca uwagę na fakt, że w filozofii Fichtego brakuje miejsca na prawdę w sensie „das Wahre”: „Pan [Jacobi zwraca się do Fichtego I. N.] nie poświęca w ogóle uwagi temu, co ja rozumiem pod pojęciem prawdy, i - takie jest moje zdanie - jako naukowcowi nie wolno Panu tego czynić." (J, 11). $\mathrm{Z}$ tego powodu formułuje on pod adresem Fichtego zarzut, że ten $\mathrm{w}$ ramach swojej filozofii nieostrożnie zabiera głos w sprawach religii, co z kolei musi prowadzić do nieuchronnego konfliktu z teizmem "rozumu naturalnego” (J, IX). Jacobi czyni tutaj aluzję do słynnego "sporu o ateizm” („Atheismusstreit”), który Fichte wywołał w Niemczech w roku 1798 swoim artykułem Über den Grund unseres Glaubens an eine göttliche Weltregierung (Hirschberger 1952, 363).

Prawdę w sensie „das Wahre” można uchwycić jedynie uczuciem; Jacobi używa w tym kontekście sformułowania „mgliste przeczucie prawdy” („Ahndung des Wahren”, J, 28). Rozum nie poznaje wprawdzie tak rozumianej prawdy, ale ją „zakłada” i na nią „wskazuje”:

Pod pojęciem prawdy [„unter dem Wahren”] rozumiem coś, co jest przed i poza wiedzą, coś, co nadaje wiedzy i rozumowi zdolnemu do jej osiągnięcia wartość. [...] Posłyszenie zakłada istnienie czegoś, co daje się posłyszeć, rozum - istnienie prawdy: jest on zdolnością założenia istnienia prawdy. Rozum, który tego nie czyni, jest niedorzecznością. [...] Wraz $\mathrm{z}$ rozumem człowiekowi nie jest dana zdolność do nauki o prawdzie, lecz jedynie poczucie i świadomość jego niewiedzy w tym zakresie: mgliste przeczucie prawdy [„Ahndung des Wahren"]. [...] Gdzie brak wskazania na prawdę, tam nie ma rozumu. Istotę rozumu stanowi właśnie owo wskazanie, owa konieczność, aby postrzegać prawdę, jawiącą się rozumowi jedynie jako mgliste przeczucie, jako jego przedmiot, jako ostateczny cel jego wszelkich dążeń 
poznawczych. Rozum jest nastawiony wyłącznie na to, co ukryte pod zjawiskami, na ich znaczenie, na sam byt, który jawiąc się, musi przecież sam przeświecać w zjawiskach, jeśli te nie mają być jedynie zjawami samymi w sobie, zjawiskami czegoś, czego nie ma (J, 27n.).

Irracjonalizm Jacobiego polegający na tym, że odmawia on rozumowi poznania prawdy w sensie „das Wahre”, zostaje zatem złagodzony tezą, że istotą rozumu jest „wskazanie” na prawdę. Gdyby człowiek nie posiadał rozumu, nie posiadałby również „mglistego przeczucia prawdy”.

\subsection{Istnienie Boga jako gwarancja realności świata}

Jacobi formułuje następującą (rozłączną) alternatywę: „Człowiek stoi przed następującym - jedynym - wyborem: nicość [„das Nichts”] albo Bóg. Jeśli wybierze nicość, to uczyni się Bogiem, a to oznacza: uczyni widmo [„,ein Gespenst"] Bogiem. Albowiem jeśli założymy, że Bóg nie istnieje, to nie jest możliwym, aby człowiek oraz wszystko to, co go otacza, nie stał się widmem." (J, 48n.). Jacobi podkreśla, że „trzeciej możliwości nie ma” (J, 49).

Wybór nicości wiąże się $\mathrm{z}$ wyborem idealizmu transcendentalnego, który będąc "filozofią wiedzy” prowadzi do „nihilizmu” (J, 39). Jacobi objaśnia to następująco: „Filozofowanie czystego rozumu musi być zatem chemicznym procesem, w którym wszystko poza nim [rozumem - I. N.] zostaje przekształcone w nicość, pozostawiając jedynie czysty rozum. Ten jest jednak tak czystym duchem, że w tej swojej czystości nie może być, lecz może jedynie stwarzać.” (J, 14n.). Jacobi podkreśla, że słowo „rozum” (które w języku niemieckim brzmi „Vernunft”) wywodzi się od słowa „vernehmen”, które znaczy tyle co „posłyszeć”, i konstatuje: „Czysty rozum słyszy tylko sam siebie” („die Reine Vernunft vernimmt nur sich”, J, 14). Prowadzi to do „abstrakcji”, „rozpuszczenia całej substancjalności w wiedzy”, „unicestwienia przez pojęcia” (J, 18). Jacobi mówi w tym kontekście o „logicznym entuzjazmie” (J, 22) oraz o „grach”: „Nasze nauki są jako takie grami [,Spiele”], które duch ludzki wymyśla dla zabicia czasu. Wymyślając owe gry, organizuje on jedynie swoją niewiedzę, nie przybliżając się do poznania prawdy [w sensie „das Wahre" - I. N.] ani o jotę." (J, 24).

Wyborem przeciwnym do wyboru idealizmu i jego konsekwencji: nihilizmu, jest wybór Boga. Jacobiemu chodzi tutaj o Boga, który jest „poza mną”, który jest „żywym samoistnym jestestwem” (J, 49), a nie „tylko myślą powstałą w skończoności" (J, 48), jak to ma miejsce w idealizmie. Wiara w Boga idealizmu to „sztuczna wiara”, która prowadzi do zniesienia „naturalnej wiary”, a tym samym do zniesienia siebie samej (J, IXn.). Realny Bóg „poza mną" jest możliwy do pomyślenia jedynie jako przedmiot wiary. Tym niemniej, jest to wiara, która rodzi się w refleksji intelektualnej, polegającej na dostrzeżeniu ograniczeń rozumu: 
Tak jak pewnym jest, że posiadam rozum, tak pewnym jest również i to, że posiadając mój ludzki rozum, nie posiadam doskonałości życia, pełni dobra i prawdy. I jak pewnym jest, że wraz z rozumem nie posiadam tego wszystkiego, i o tym wiem, tak wiem również na pewno, że istnieje istota wyższa, z której biorę swój początek. Dlatego maksymą mojego rozumu nie jest słowo „ja”, lecz: Więcej niż ja! Lepiej niż ja! - ktoś całkiem inny [...]. I tak rozum poucza mnie w sposób instynktowny o Bogu (J, $30)$.

Wiara człowieka jest zatem skutkiem intelektualnego odkrycia jego własnej niedoskonałości. Rozum poucza człowieka o istnieniu Boga, nie mogąc jednak pojąć tego istnienia. Jacobi wyraża to $\mathrm{w}$ ten sposób, że rozum „zmusza człowieka do wierzenia w coś, czegoś nie da się pojąć, i co pojęciowo nie jest możliwe” („das im Begriff ?nmmögliche”, J, 31).

Chcąc podkreślić różnicę pomiędzy idealizmem kantowskofichteańskim a swą własną filozofią, Jacobi charakteryzuje ją jako "filozofię nie-wiedzy” („Philosophie des Nicht-Wißens”, J, 39) i „naukę o niewiedzy” („?nwißenheitslehre”, J, 54). Jedynie taka filozofia umożliwia, jego zdaniem, założenie realnej egzystencji Boga, bez której realność świata zanika. W wydanej w roku 1801 pracy Über eine Weissagung Lichtenbergs Jacobi stwierdza: „Nie może być inaczej: wraz z negacją stwórcy ginie również całe stworzenie. Losy obydwu są nierozerwalnie splecione w ludzkim duchu. Jeśli Bóg staje się dla człowieka widmem, to wkrótce staje się nim również natura, wkrótce także jego własny duch.” (Jacobi 1801, 6). Dlatego ktoś, kto narusza wiarę w Boga, jest „wrogiem ludzkości” (J, 53): „Albowiem żadna nauka i żadna sztuka, lub cokolwiek innego, nie mogłyby zwrócić człowiekowi tego, co przepadłoby wraz z wiarą." (J, 53). Charakteryzując swoją drogę życiową jako filozofa, Jacobi stwierdza: „Jak mało kto, z żarliwością i powagą poszukiwałem od dziecka prawdy; i jak mało kto poznałem swoją niemoc. Moje serce, drogi Fichte, stało się wskutek tego łagodne, och, jakże łagodne, a mój głos jakże cichy!" (J, 39n.). Podobnie jak św. Augustyn, Jacobi, poszukując prawdy, odnajduje ją ostatecznie w religii chrześcijańskiej i związanej z nią pokorą (św. Augustyn 2008, 100n.).

\section{Konsekwencje dla etyki i wolności}

Scharakteryzowane w części pierwszej niniejszego szkicu poglądy Jacobiego stanowią fundament jego etyki i filozofii wolności. Podobnie jak w kwestii poznania, także w odniesieniu do dziedzin stricte praktycznych Jacobi z jednej strony docenia osiągnięcia idealizmu Kanta i Fichtego, z drugiej zaś strony poddaje go krytyce: ostatecznym uzasadnieniem etyki i wolności nie jest rozum, lecz uczucie i wiara. Co ciekawe, Jacobi - podobnie jak Kant uzasadnia realność wolności za pomocą argumentu etycznego, i dlatego jako pierwsza naszkicowana zostanie problematyka etyczna. 


\subsection{Etyka}

W kontekście etyki centralne znaczenie mają przywołane już wcześniej słowa Jacobiego, mówiące o tym, że człowiek posiadając rozum, nie posiada pełni dobra (J, 30). Jacobi wskazuje tu najwyraźniej - choć nie wprost - na problem zła. Idealizm kantowsko-fichteański postrzegał rozum jako wystarczający środek służący rozwiązaniu tego problemu: działanie moralnie dobre to działanie rozumne. Jacobi docenia to osiągnięcie idealizmu: „Ale czyż ja pragnę, żeby nie mogła zostać ustanowiona żadna ściśle dowiedziona nauka o obowiązkach, która jest możliwa jedynie w oparciu o czysty system rozumowy? Czyż nie dostrzegam wartości tego rodzaju dyscypliny i zaprzeczam korzyściom z niej płynącym? Czyż kwestionuję prawdę i wzniosłość zasady, od której wychodzi nauka o moralności oparta na czystym rozumie? W żadnym wypadku! Rozumowa zasada moralna, czyli zgodność człowieka z samym sobą i stała jedność, jest czymś pojęciowo najwyższym, a to dlatego, że jedność ta jest absolutnym i niezmiennym warunkiem rozumnej egzystencji jako takiej, a zatem również każdego rozumnego i wolnego działania. Jedynie w niej i z nią człowiek może posiąść prawdę [„Wahrheit”] i życie wyższe." (J, 34n.).

Tym niemniej, redukcja etyki do czysto intelektualnej nauki jest wielkim błędem, albowiem etyka taka nie wyraża prawdy w sensie „das Wahre”: „Ale sama jedność nie jest istotą, nie jest prawdą [„das Wahre”]. Sama w sobie jest ona całkowicie pusta. Tak więc, jej prawo nie może stać się nigdy sercem człowieka i rzeczywiście wynieść go ponad niego samego. To ostatnie potrafi uczynić tylko serce zdolne do tworzenia [„Vermögen”] idei, które nie są puste. Filozofia transcendentalna nie może wyrwać mi tego serca z piersi, wstawiając w to miejsce czysty popęd samej tylko jaźni. Nie dam się uwolnić od bycia zależnym od miłości, ażeby jedynie poprzez pychę stać się szczęśliwym. Jeśli moje puste i czyste, nagie i ogołocone ja, z całą swą samodzielnością i wolnością, jest najwyższym przedmiotem mojej refleksji i oglądu, to wtedy refleksyjny ogląd samego siebie oraz sama rozumność stają się dla mnie przekleństwem. Przeklinam swoją egzystencję." (J, 35). Jacobi odwołuje się zatem do swojego fundamentalnego poglądu, głoszącego, że rozum i prawda w sensie „das Wahre” nie są tym samym. „Rozumowa zasada moralna, czyli zgodność człowieka z samym sobą i stała jedność, jest czymś pojęciowo najwyższym”, ale jednocześnie czymś „pustym”. Tego typu zasadą moralną jest imperatyw kategoryczny Kanta, w którym Jacobi nie dostrzega „niczego tajemniczego" (J, 38). Jest ona wprawdzie warunkiem koniecznym działania moralnego, ale nie jest warunkiem wystarczającym. Wyraża ona prawdę w sensie "Wahrheit”, ale nie w sensie „das Wahre". Wyrazem tej ostatniej prawdy są bowiem „serce” i „miłość”. To uczucia, a nie rozum, są dla Jacobiego fundamentem etyki, ponieważ to właśnie one reprezentują najwyższą prawdę etyczną. 
Same uczucia nie stanowią jednak ostatecznego uzasadnienia etyki: „Ale dobro - czym ono jest? Nie znajduję odpowiedzi, jeśli nie ma Boga." (J, 31). Ten pogląd Jacobiego staje się zupełnie jasny, jeśli uwzględni się jego zasadnicze przekonanie, że człowiek stoi przed alternatywą: albo Bóg albo nicość. ${ }^{3}$ Jeśli Boga nie ma, to również i uczucia stają się nicością, „widmem”. „Czysta miłość” człowieka ukierunkowana jest na „wieczność” (J, 94). „Życie wieczne jest istotą duszy" (J, 100). Miłość człowieka do Boga jest aktem wolności („freye Liebe”, J, 47). Podkreślając związki religii z etyką, Jacobi odwołuje się do biblijnej prawdy głoszącej, że Bóg stworzył człowieka „na swoje podobieństwo” (J, 46). Skoro tak, to Bóg jest również „w nas”, co z kolei pozwala człowiekowi skierować się do Boga poza nim. Jacobi podejmuje tutaj najwyraźniej teologiczny temat przebóstwienia człowieka, choć analizując to zagadnienie, nie porusza problemu łaski.

Konieczność wiary w Boga, jako warunku urealniającego etykę, Jacobi charakteryzuje w następujący sposób: „Jeśli świat zjawisk objawia w nich samych całą swoją prawdę, a nie jakieś głębiej ukryte znaczenie, jeśli poza samym sobą nie objawia on już nic, to świat ten staje się upiorną zjawą, wobec której przeklinam świadomość, która doprowadziła do jej powstania i wzywam - jak wzywa się bogów - do jej unicestwienia. Podobnie wszystko to, co określiłem jako dobre, piękne i święte, staje się niszczącą mego ducha i wyrywającą me serce niedorzecznością, jeśli przyjmę, że owe wartości nie mają związku z prawdziwą istotą wyższą, będącą czymś więcej niż jej obraz we mnie: jeśli miałbym w sobie jedynie pustą świadomość i poetycki twór [„Gedicht”].” (J, 31n.). Jacobi nie podważa tezy, że naukową pewność etyka może uzyskać jedynie na drodze idealizmu. Ale właśnie usiłowania, aby sprowadzić etykę do nauki, prowadzą w niewłaściwym kierunku: „Nie uczcie mnie tego, co wiem i co potrafię wykazać lepiej niżby wam to dogadzało; mianowicie, tego, że owa wola, która nic nie chce, owa bezosobowa osobowość [„unpersönliche Persönlichkeit"], owo całkowicie puste bezosobowe ja [,jene bloße Ichheit des Ich ohne Selbst"], jednym słowem: że jedynie czyste i nagie widma są fundamentem, na którym można zbudować powszechnie ważny, ściśle naukowy system moralności. Ze względu na pewność naukową musicie - nie możecie inaczej! - podporządkować sumienie [...] żywemu trupowi racjonalności. Musicie je uczynić czymś ślepo posłusznym prawu, głuchym, niemym, beznamiętnym. Musicie całkowicie oderwać od człowieka żywe źródło sumienia, którym jest jego serce. Musicie to uczynić, ponieważ mimo waszych marzeń o niebie, Apollo i muzy to dla was jedynie kategorie! Tylko w ten sposób bezwarunkowe prawa powszechne, reguły bez wyjątku oraz sztywne posłuszeństwo staną się możliwe. Tylko w ten sposób sumienie może mieć pewność również co do oceny czynów zewnętrznych i wszem i wobec pouczać ex cathedra o swojej nieomylności.” (J, 33n.).

\footnotetext{
${ }^{3}$ Por. rozdz. 1.1.
} 
Do możliwych zarzutów, mogących się pojawić w związku z jego krytyką idealizmu, Jacobi ustosunkowuje się w następujący sposób: „Wyznaję zatem, że nie znam 'dobra samego w sobie', lecz że mam jedynie jego odległe, mgliste przeczucie [„eine ferne Ahndung”]. Oświadczam, że oburza mnie, kiedy chcą mnie przymusić do uznania woli, która nic nie chce, owej pustej skorupy samodzielności i wolności w czymś absolutnie nieokreślonym, i kiedy oskarżają mnie o ateizm, tę prawdziwą i właściwą bezbożność, gdy odmawiam przyjęcia takiej woli $\mathrm{w}$ miejsce przeczucia. [...] Jestem tym bezbożnikiem i drwię z filozofii, która z tego powodu nazywa mnie bezbożnym; drwię z niej i z jej najwyższej istoty. Albowiem za sprawą najświętszej pewności, którą noszę w sobie, wiem że to privilegium aggratiandi [przywilej ułaskawienia - I. N.] związane z wykroczeniami przeciwko czystej literze absolutnie powszechnego prawa rozumu jest właściwym królewskim prawem człowieka, pieczęcią jego czci i boskiej natury." (J, 32n.). W tym kontekście jaśniejsza staje się wyrozumiałość Jacobiego wobec tzw. przesądów religijnych („Aberglaube”) zwalczanych przez idealizm. ${ }^{4}$ Poddaje on je wprawdzie krytyce, jeżeli nie towarzyszy im wewnętrzna wiara człowieka. Ale już w przypadku, gdy człowiek wierzy i jednocześnie ulega pewnym „przesądom”, Jacobi staje się bardziej wyrozumiały: „Obwinianie przesądów nie powinno nam przychodzić zbyt łatwo" („Die Beschuldigung [...] des Aberglaubens sollte uns nicht so leicht aus dem Munde gehen" J, 52). W stwierdzeniu tym wyraźnie uwidacznia się opozycja Jacobiego wobec ducha filozofii oświeceniowej i idealistycznej. Trudno byłoby wyobrazić sobie na przykład Kanta wypowiadającego podobne słowa.

\section{b) Wolność}

Podobnie jak to miało miejsce w przypadku etyki, Jacobi szuka fundamentów wolności w sferze prawdy rozumianej nie jako „Wahrheit”, lecz „das Wahre”. Wolność jest, jego zdaniem, niemożliwą do zbadania tajemnicą („unerforschliche[s] Geheimniß der Freiheit”, J, 38). Jest ona pojęciem, które przekracza rozum (der „die Vernunft übersteigende Begriff der Freyheit”, J, 45). Tym samym Jacobi dystansuje się od idealizmu kantowsko-fichteańskiego, który utożsamił wolność z racjonalnością. Aby wyjaśnić swój pogląd na temat wolności, Jacobi bada relacje zachodzące pomiędzy rozumem a wolnością. Swoje rozważania rozpoczyna od następującego zasadniczego pytania: „Czy człowiek posiada rozum, czy rozum posiada człowieka?” (J, 65). W pierwszym przypadku Jacobi charakteryzuje rozum jako „adjective Vernunft”, w drugim jako „substanive Vernunft”. Sądzi on, że właśnie to rozróżnienie ma fundamentalne znaczenie dla kwestii wolności: „Różnica, na którą wskazuje

${ }^{4}$ Słowo „Aberglaube” (przesąd, zabobon) ma w filozofii idealistycznej specyficzne znaczenie: przesądem jest wszystko to, co nie jest zgodne z tą filozofią. Porównaj krytykę praktyk religijnych przeprowadzoną przez Kanta w: Kant, Religia w obrębie samego rozumu, tłum. A. Bobko, Kraków: Homini 2007, s. 226, 250n. 
powyższe pytanie - różnica pomiędzy rozumem substancjalnym [„,substantive Vernunft"] utożsamianym z całym duchem człowieka [„Geist des Menschen”] a rozumem atrybutywnym [,adjective" Vernunft], który sam w sobie nie jest substancją [„Wesen”], lecz cechą i właściwością substancji - musi stanowić podstawę nauki o wolności, ponieważ $\mathrm{w}$ przeciwnym wypadku nauka ta stanowić będzie próżny sofistyczny twór [„Gewebe”], który nie wytrzyma krytyki bardziej wnikliwego badania." (J, 65n.).

Dokonując powyższego rozróżnienia, Jacobi wskazuje na fakt, że duch człowieka („Geist”) i jego rozum nie są tożsame. Idealizm popełnia zasadniczy błąd, utożsamiając oba te pojęcia. Jacobi stwierdza:

Rozróżnienie to można odnaleźć także w filozofii Kantowskiej, ale pojawia się tam ono tylko chwilowo, aby natychmiast ponownie zniknąć. Powód tego jest oczywisty: Dzieje się tak, albowiem duch ["Geist"] nie nadaje się do naukowego badania, ponieważ nie może on stać się literą. Duch musi zatem pozostać na zewnątrz, przed bramami nauki o nim. Tam, gdzie jest nauka, tam nie może być jego. Dlatego ten, komu wydaje się, że „literuje” ducha, z pewnością literuje - świadomie lub nie - zawsze coś innego. Innymi słowy: dążąc do przekształcenia ducha $w$ literę, przekreślamy nieuchronnie ducha, a litera, która podaje siebie za ducha, kłamie. Kłamie, ponieważ nigdy nie jest literą ducha to, co przypisuje sobie tę nazwę. Mamy tu zatem do czynienia z czystym oszustwem, ponieważ prawdziwy duch nie posiada litery. Oczywiście, także litera ma swojego ducha, a duch ten zwie się nauką $(J, 67)$.

Dążenie filozofii idealistycznej do tego, aby zastąpić ducha rozumem („literą”), musi prowadzić do negacji wolności. Jacobi twierdzi tak, gdyż jego zdaniem rozum tożsamy jest z koniecznością, a ta wyklucza wolność. Rozum to: „reprezentant konieczności, która przemocą wszystko już określiła, i nie dopuszcza do dziania się niczego, co już by się wcześniej nie wydarzyło [...]” (J, 69). Istota rozumu leży wyłącznie w sferze pojęć („die Vernunft, die im Begreiflichen allein ihr Wesen hat", J, 68), a te nie są wyrazem wolności, lecz konieczności logicznej. Pod pojęciem „mechanizm” Jacobi rozumie „każde konieczne powiązanie” („jede nothwendige Verkettung”, J, 62), i dlatego rozum jest dla niego ostatecznie jedynie mechanizmem. Jako taki jest on czymś ograniczonym, czymś „czasowym” („zeitliche Vernunft”, J, 70). Rozum tak pojmowany leży - zgodnie z idealistyczną doktryną, którą Jacobi w tym właśnie punkcie w pełni podziela - u podłoża mechanizmu przyrody. Rozum, konieczność, mechanizm, czas i przyroda zlewają się u Jacobiego w jedno. Dlatego też sądzi on, że idealizm prowadzi do absurdalnego poglądu, iż dzieła Platona, Kanta czy Fichtego oraz wszystkie czyny słynnych postaci historycznych są wytworami konieczności, a nie wolności (J, 70).

Aby uratować wolność, należy, zdaniem Jacobiego, postrzegać rozum jako „rozum atrybutywny”, tzn. rozum będący jedynie atrybutem ducha. Duch 
jest czymś więcej niż rozum, i właśnie w tej pozarozumowej „części” ducha ma swoje źródło wolność: „To, co duch dodaje od siebie, jest czymś niemechanicznym w działaniach, uczynkach i charakterach ludzkich, czymś, co nie wywodzi się z powszechnego prawa przyrody, lecz z pewnej osobliwej siły [„eigenthümliche Kraft”].” (J, 69). Relację rozum-wolność Jacobi charakteryzuje w następujący sposób: „Jedynie duch, a nie przyroda, działa w sposób celowy. Tylko on tworzy i dąży do czegoś. Wytwory samej tylko przyrody są ślepe, bezrozumne, konieczne, czysto mechaniczne; brak tutaj opatrzności, planu, wolnego wyboru i celu. Dlatego też rozum i wolność są w naszej świadomości czymś nierozłącznym, ale nie w taki sposób, że władza wolności musi zostać wywiedziona od rozumu (Adjectivo), tylko tak, że rozum musi zostać wywiedziony od władzy wolności (Substantivo)." (J, 68).

Rozum i wolność są zatem czymś „nierozłącznym”, ale to wolność człowieka jest czymś fundamentalnym, podczas gdy rozum jedynie jej służy. Samo pojęcie wolności Jacobi charakteryzuje w następujący sposób: „Poprzez słowo 'wolność' rozumiem tę władzę człowieka, dzięki której on samodzielnie istnieje i samodzielnie - w sobie oraz poza sobą - działa, oddziałuje i wytwarza. Postrzegając i odczuwając siebie jako istotę wolną, człowiek uważa się za stwórcę swoich własnych cech osobistych, nauki i sztuki, a także swoich intelektualnych i moralnych właściwości charakteru. Siebie samego postrzega jako twórcę i stwórcę tego wszystkiego." (J, 67). Wolności w tym sensie nie da się udowodnić rozumowo (J, 71): sfera wolności jest obszarem nieprzezwyciężalnej niewiedzy („Gebiet der Unwißenheit”, J, 72), a sama wolność jest sprawą wiary („Glaube an Freyheit”, J, 72). Jacobi sądzi, że skuteczna obrona wolności jest możliwa tylko dzięki wyodrębnieniu „niedostępnego dla nauki terenu prawdy":

Jeśli sprawa ma wyglądać inaczej, jeśli nie chcemy, aby szaleństwo było elementem boskim $\mathrm{w}$ człowieku, a prawda i oczyszczony rozum elementem nie-boskim, to niewiedza związana $\mathrm{z}$ wiarą $\mathrm{w}$ wolność musi być całkowicie innego rodzaju: musi być ona owym niedostępnym dla nauki terenem prawdy. 'Zdejmij buty, albowiem tutaj zaczyna się święty kraj!' (J, 73).

Nie mogąc rozumowo „udowodnić” wolności, Jacobi podaje jednak pewien istotny argument przemawiający za jej realnością. Odwołuje się on mianowicie do przeżyć moralnych, których doświadcza człowiek: „My natomiast twierdzimy: nie jest możliwym, aby wszystko było naturą, a nie wolnością, ponieważ nie jest możliwym, aby wszystko to, co człowieka uszlachetnia i wznosi: prawda [„das Wahre”], dobro i piękno, było jedynie iluzją, oszustwem i kłamstwem. A właśnie tym byłoby, jeśli nie istniałaby wolność. Prawdziwy szacunek, prawdziwy podziw, prawdziwa wdzięczność i miłość nie są możliwe, jeśli nie jest możliwym, aby w jednym jestestwie mieszkały razem wolność i przyroda, jeśli ta pierwsza nie rządziłaby tam, gdzie swą nić tka ta druga. Wobec maszyny i automatu (obojętnie, czy duchowego czy cielesnego) 
człowiek nie jest w stanie odczuwać szacunku, kochać go, dziękować mu lub choćby go podziwiać. Podziwiając maszynę lub automat, zawsze podziwiamy ukrytą w nich sztukę, ducha, który rozumnie [„mit Einsicht”] i celowo je wytworzył. Owe uczucia odnoszą się tylko do ducha, tylko i wyłącznie do zdolności, która nie jest działaniem mechanicznym, lecz która działa, określa i wytwarza nie w sposób pojęciowo możliwy, lecz w sposób pojęciowo (albo: naturalnie) niemożliwy.

[...] Jeśli szydząc wzywasz mnie do tego, abym w jakimkolwiek pojedynczym uczynku, działaniu i charakterze ludzkim oddzielił udział natury od udziału wolności, i abym podał, jak można odróżnić jedno od drugiego, to ja ze swej strony, bez szyderstwa, wzywam cię do tego, abyś - odczuwając podziw, szacunek, wdzięczność i miłość - nie czynił tego rozróżnienia. Abyś nie wyobrażał sobie, że obok oddziaływania naturalnego istnieje jeszcze wolność, i abyś wzbudzonych w sobie uczuć nie odnosił jedynie do niej. Wiem, że będzie to dla ciebie czymś niemożliwym. Utracisz te uczucia, jeśli pominiesz wolność, jeśli uczynisz ją czymś najzupełniej zbędnym (J, 71n.).

Argument moralny, którym posługuje się Jacobi, można scharakteryzować w następujący sposób: Uczucia moralne są faktem i właśnie one dowodzą wolności człowieka, bez której w ogóle by nie zaistniały.

\section{Konkluzje}

Analiza filozofii Jacobiego prowadzi do zasadniczego pytania, w jakim stopniu jest ona uwikłana $\mathrm{w}$ rozwiązania idealizmu transcendentalnego, a $\mathrm{w}$ jakim stopniu jest od tego idealizmu niezależna. Głosząc dualizm prawdy, Jacobi nawiązuje niewątpliwie do myśli Kanta. Kantowska prawda teoretyczna staje się u niego prawdą w sensie „Wahrheit”; nie dotyczy ona rzeczywistości samej w sobie, lecz „zjawisk” będących wytworem człowieka. Podobnie jak Kant Jacobi zakłada, że u podłoża tych zjawisk leży jakaś rzeczywistość niezależna od człowieka. To realistyczne założenie odróżnia ich myśl od filozofii Fichtego. Tym niemniej, nie jest to realizm w sensie przedkantowskim, albowiem zarówno Kant jak i Jacobi głoszą tezę o niemożliwości intelektualnego poznania tej rzeczywistości. Paradoks ten niezwykle silnie widoczny jest $\mathrm{u}$ Kanta; Jacobi stara się go złagodzić, wskazując na możliwości pozarozumowego, intuicyjnego poznania. W ten sposób staje on w wyraźnej opozycji wobec Kanta, dla którego taki rodzaj poznania nie przedstawia filozoficznej wartości. Różnica pomiędzy nimi jest szczególnie widoczna w odniesieniu do problemu istnienia Boga. Kant sądzi, że problem ten jest intelektualnie nie do rozstrzygnięcia (Kant 1787, B 669), lecz jednocześnie twierdzi, że Bóg jest konieczną ideą (lub: „postulatem”) rozumu. Jest to trudny i niejasny moment w jego filozofii (Sala 2004, 293nn., 314nn.). Zupełnie inaczej postępuje Jacobi. W jego ujęciu rozum (idealistyczny) z konieczności 
dochodzi do negacji istnienia Boga, i tylko wyodrębnienie niezależnej od rozumu sfery intuicyjnej, może temu zapobiec.

Dualistyczna filozofia Jacobiego składa się zatem z dwóch zasadniczych elementów: prawdy intelektualnej i prawdy intuicyjnej, i ten właśnie moment odróżnia ją od dualizmu Kantowskiego, który jest dualizmem w obrębie rozumu. U Kanta rozum „rozpada” się na dwie części: teoretyczną i praktyczną, i odpowiednio do tego „rozpada” się prawda. Sytuację komplikuje dodatkowo fakt, że zarówno w obrębie rozumu teoretycznego jak i praktycznego Kant wyróżnia sferę wiedzy i sferę wiary (Kant 1787, B XXIXn.). Idea wolności jest $\mathrm{w}$ filozofii teoretycznej Kanta przedmiotem wiary, natomiast $\mathrm{w}$ filozofii praktycznej staje się przedmiotem (praktycznej) wiedzy. W odróżnieniu od Jacobiego, Kant stara się uzasadnić wiarę intelektualnie, zupełnie pomijając uzasadnienia innego rodzaju.

Dostrzegając zasadniczą różnicę pomiędzy dualizmem Kanta i Jacobiego, można zadać jednakże pytanie, czy intuicyjna sfera prawdy u Jacobiego z jednej oraz racjonalna wiara Kanta z drugiej strony nie wykazują pewnych podobieństw. Można by nawet posunąć się jeszcze dalej i zastanowić się, czy podobieństwa te nie występują w odniesieniu do prawdy praktycznej (etyki) Kanta. Jeśli chodzi o pierwszą kwestię, to podobieństwo między Kantem a Jacobim polega na tym, że obaj pojmują wiarę jako nie-wiedzę. To, że dla Kanta wiara ma charakter racjonalny, a dla Jacobiego - intuicyjny, nie może podważyć tej zasadniczej zbieżności. Nasuwa się jednak pytanie, czy Kant, obalając dowody „starej metafizyki” i lokując sferę wiary poza obrębem wiedzy, jest przekonujący, głosząc racjonalność wiary. Druga kwestia dotyczy podobieństw pomiędzy prawdą praktyczną Kanta a prawdą intuicyjną Jacobiego. Na pierwszy rzut oka mogło by się wydawać, że w ogóle ich nie ma, gdyż Kant utrzymuje przecież, że jego etyka ma charakter czysto racjonalny, a zatem naukowy. Ale właśnie z tą tezą Kanta można polemizować. Wiedza teoretyczna znajduje potwierdzenie w naukach matematycznoprzyrodniczych. Nauki te milczą jednak na temat etyki (Heisenberg 1968). Dlatego Kant stara się uzasadnić swoją filozofię moralną, odwołując się do „czystego rozumu”. Pytanie tylko, czy rozum taki w ogóle istnieje, a jeśli tak, to czy Kant, uzasadniając etykę, odwołuje się wyłącznie do niego. Wydaje się raczej, że nawiązuje on do historycznej etyki chrześcijańskiej, którą zakłada jako coś oczywistego i stara się ją uzasadnić rozumowo. Z tego względu teza o podobieństwie pomiędzy prawdą praktyczną Kanta a prawdą intuicyjną Jacobiego nie jest bezpodstawna.

Powyższe rozważania prowadzą do następującej konkluzji. Jeśli spojrzeć na filozofię Kanta jako na dualizm wiedzy teoretycznej oraz całej reszty poznania (wiara, wiedza praktyczna), to wówczas podobieństwo pomiędzy filozofią Kanta a filozofią Jacobiego jest bardzo widoczne. Fakt ten nie powinien jednakże zaciemnić podstawowej różnicy pomiędzy Kantem i Jacobim. Kant, a po nim kolejni przedstawiciele filozofii idealistycznej: Fichte i 
Hegel, odrzucają intuicję, uczucia i wiarę jako sposoby poznania, i stawiają w centrum swojego zainteresowania rozum. Jacobi odrzuca taką metodę, ponieważ sądzi, że redukcja poznania filozoficznego do poznania racjonalnego prowadzi nieuchronnie do negacji wolności i etyki. Podobnie jak Kant Jacobi uważa, że wolność i konieczność wykluczają się nawzajem. W odróżnieniu od Kanta uważa on jednak, że racjonalność i konieczność są tym samym, i w tym właśnie punkcie leży - jak się wydaje - najgłębsza różnica pomiędzy filozofią Jacobiego a idealizmem transcendentalnym Kanta oraz jego następcy Fichtego.

Wyróżniając sferę poznania intuicyjnego, Jacobi stara się bronić moralno-religijnych poglądów, które ukształtowały się w zachodnim kręgu kulturowym. Błąd przedstawicieli idealizmu transcendentalnego polega, jego zdaniem, na tym, że dążą oni do przeformowania tych poglądów w duchu swojej filozofii. Ostateczną konsekwencją tych usiłowań jest jednak zniszczenie wiary w Boga, wolność i wartości etyczne. George di Giovanni, charakteryzując filozofię Jacobiego, stwierdza: „In all cases, his opposition to the philosophers was based on his belief that their passion for explanation unwittingly led them to confuse conditions of conceptualization with conditions of existence, thereby denying all room for individual freedom or for a personal God." (Giovanni 2010). Celem idealizmu transcendentalnego - na co zwraca uwagę Robert Spaemann - nie była bowiem pokojowa koegzystencja religii i idealizmu, lecz raczej podporządkowanie tej pierwszej temu drugiemu (Spaemann 2010, 80nn.). Jacobi najwyraźniej sprzeciwia się tej hegemonistycznej tendencji i próbuje uzgodnić pewne elementy idealizmu transcendentalnego (nauka) z religią chrześcijańską (wiara). Warunkiem takiego zharmonizowania jest uznanie przez człowieka ograniczoności rozumu i przyznanie pierwszeństwa wierze. Czy filozofia Jacobiego jest zatem irracjonalizmem (lub: fideizmem) czy racjonalizmem? Odpowiedź nie jest łatwa i zależy od tego, w którym miejscu zostaną postawione akcenty. George di Giovanni zwraca uwagę na to, że sam Jacobi nigdy nie postrzegał siebie jako irracjonalistę (Giovanni 2010). ${ }^{5}$

Kluczem do zrozumienia filozofii Jacobiego wydaje się być jej egzystencjalny aspekt. Akt wyboru niewiedzy, tajemnicy i wiary jest aktem pokory, a zatem aktem egzystencjalnym. Charakterystyczne jest, że Jacobi bardzo pozytywnie odnosi się do słynnego stwierdzenia Fichtego, mówiącego o tym, że o wyborze określonej filozofii decyduje osobowość człowieka (J, 55). Akcentując moment egzystencjalny oraz wiążąc ten moment ściśle z religią, Jacobi nawiązuje do religijno-egzystencjalnej tradycji filozoficznej, do św. Augustyna i Pascala. Linię tę kontynuują w XX wieku liczni przedstawiciele fenomenologii (np. M. Scheler, D. v. Hildebrand i W. Schapp). W tym kontekście

\footnotetext{
${ }^{5}$ Stwierdza on: „[...] he never considered himself an irrationalist; on the contrary, that he thought his 'faith' to be essentially and truly rational; and that he tried more than once to develop a positive theory of reason."
} 
warto też wymienić pisarza-myśliciela F. Dostojewskiego, którego krytyka nowożytnej filozofii wykazuje wiele punktów zbieżnych z myślą Jacobiego.

\section{Literatura}

Św. Augustyn z Hippony. 2008. Wyznania (Confessiones). Tłum. Jan Czuj. Kraków: AA.

Giovanni, G. 2010. Hasło "Friedrich Heinrich Jacobi". W: E.N. Zalta (Ed.), The Stanford Encyclopedia of Philosophy, Spring $2010 \quad$ Edition. Dostęp http://plato.stanford.edu/archives/spr2010/entries/friedrich-jacobi/ dn. 3.07.2013.

Heisenberg, W. 1968. "Das Naturbild Goethes und die technischnaturwissenschaftliche Welt“. Physikalische Blätter 24 (1968), 5: 193200.

Hirschberger, J. 1952/1991. Geschichte der Philosophie. Neuzeit und Gegenwart. Freiburg - Basel - Wien: Herder.

Jacobi, F-H. 1799. Jacobi an Fichte. Hamburg: Friedrich Perthes. Dostęp http://www.bsb-muenchen-digital.de/ web/web1004/bsb10046116 /images/index.html?digID=bsb10046116\&pimage $=00002 \& \mathrm{v}=$ pdf\&md $=1 \& \mathrm{l}=$ de dn. 3.07.2013.

Jacobi, F-H. 1801. ⿴eber eine Weissagung Lichtenbergs. Dostęp http://www.bsb-muenchen-digital.de/ web/web1004/bsb10043530 /images/index.html?digID=bsb10043530\&pimage $=00001 \& \mathrm{v}=$ pdf \&md $=1 \& \mathrm{l}=$ de dn. 3.07.2013.

Kant, I. 1783/2005. Prolegomena do wszelkiej przyszłej metafizyki, która będzie mogła wystąić jako nauka. Tłum. A. Banaszkiewicz. Kraków: Zielona Sowa.

Kant, I. 1787/1957. Krytyka czystego rozumu. Tłum. R. Ingarden. Warszawa: PWN.

Kant, I. 1793/2007. Religia w obrębie samego rozumu. Tłum. A. Bobko. Kraków: Homini.

Sala, G-B. 2004. Kants „Kritik der praktischen Vernunft“. Ein Kommentar. Darmstadt: Wissenschaftliche Buchgesellschaft.

Spaemann, R. 2010. Das unsterbliche Gerücht. Die Frage nach Gott und die Täuschung der Moderne. Stuttgart: Klett-Cotta. 
Igor Nowikow

\title{
Jacobi i jego polemika z idealizmem transcendentalnym
}

\begin{abstract}
The subject of this article is the practical philosophy of Friedrich $\mathrm{H}$. Jacobi (1743-1819), which the author tries to reconstruct on the basis of the work entitled "Jacobi an Fichte" (1799). Jacobi distinguishes between two kinds of truth: "Wahrheit" and "das Wahre." The former is the rational truth (knowledge), the latter - the intuitive truth (faith). In his opinion, the error of transcendental idealism, the exponents of which are Kant and Fichte, is that it respects only the rational truth. However, Jacobi points to the fact that while reason and necessity are the same, the former is contradictory to individual freedom. Therefore, the concept of transcendental idealism - despite the intentions of its exponents - leads to the negation of freedom and ethics. These can be only justified by the intuitive truth, which is strongly connected with Christian religion.
\end{abstract}

Keywords: Jacobi, transcendental idealism, truth, knowledge, faith, ethics, freedom.

Ethics in Progress (ISSN 2084-9257). Vol. 4 (2013). No. 1. 91-105. 